\title{
A Brush Seals Program Modeling and Developments
}

\author{
ROBERT C. HENDRICKS *, RALPH FLOWER ${ }^{\dagger}$ and HAROLD HOWE ${ }^{\ddagger}$ \\ National Aeronautics and Space Administration, Lewis Research Center, Cleveland, OH 44135, USA \\ (Received 22 January 1997; In final form 13 February 1997)
}

\begin{abstract}
Some events of a US Army/NASA Lewis Research Center brush seals program are reviewed, and the development of ceramic brush seals is described. Some preliminary roomtemperature flow data are modeled and compare favorably to the results of Ergun.
\end{abstract}

Keywords: Brush seals, Ceramics, Porous media, Flow modeling

\section{INTRODUCTION}

Recognizing the remarkable brush seal accomplishments of Ferguson [1988] and Flower [1990], Fig. 1, NASA Lewis Research Center embarked on a program to develop the fundamentals characterizing flow and dynamics of brush seals.

The program entailed

(1) Developing a heuristic brush seal bulk flow model and code for determining the flow and pressure drop in brush seal systems that would be suitable for both designers and researchers.

(2) Utilizing an existing water tunnel facility and fabricating an experimental oil tunnel facility to visualize flows through simulated brush seal sections.
(3) Setting up an approach for determining rub characteristics, debris, bristle flexure cycles, and seal life associated with long-term operations for the brush seal and rub runner as a system (tribopairing).

(4) Integrating observations from an airflow tunnel of the flow through sequences of nylon bristle brushes, such as bristle flexure, flutter, edge loss, and clearances leakage.

Toward this end, a bulk flow model and computer code were developed. The model centered on the forces acting on a single bristle and the flow through a porous medium consisting of fibrous type materials. Although the details of the brush are proprietary, estimates of its dimensions and allowances for multiple bristles and packing were made and input into the model. By

* Corresponding author.

${ }^{\dagger}$ Cross Mfg. Ltd., Devizes, UK.

${ }^{\ddagger}$ Technetics Corp., DeLand Florida. 


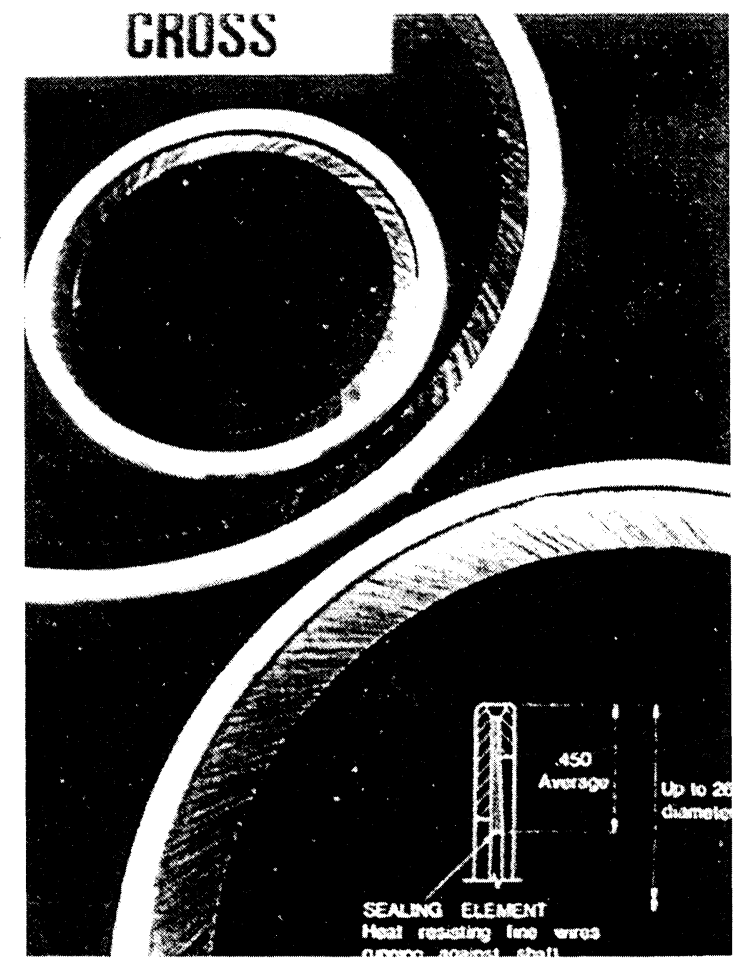

FIGURE 1 Circular brush seal (Courtesy of Cross Mfg. Ltd.).

using one data point from Cross Mfg. Ltd., the geometric and flow parameters were established, and predictions of flow and pressure drop followed as illustrated in Fig. 2.

A simulated brush seal section with Lucite bristles was fabricated and placed into a water tunnel at NASA Lewis. The flow was seeded with magnesium oxide particles and illuminated with a sheet of laser light. The light provided twodimensional slices of the flow, revealing a complexity not envisioned (Fig. 3). By moving the light beam, the tunnel was surveyed to show flows along the bristles and up and down through the bristles, revealing complex vortex attachments and surface boundary layers. Video tapes of these flow fields were made to illustrate the complexity of brush seal flows by Braun et al. [1990].

Using these flow visualization methods a special oil tunnel was fabricated as well as sets of simulated brush seal sections with Lucite bristles. Because the refraction indexes of the Lucite and the oil were

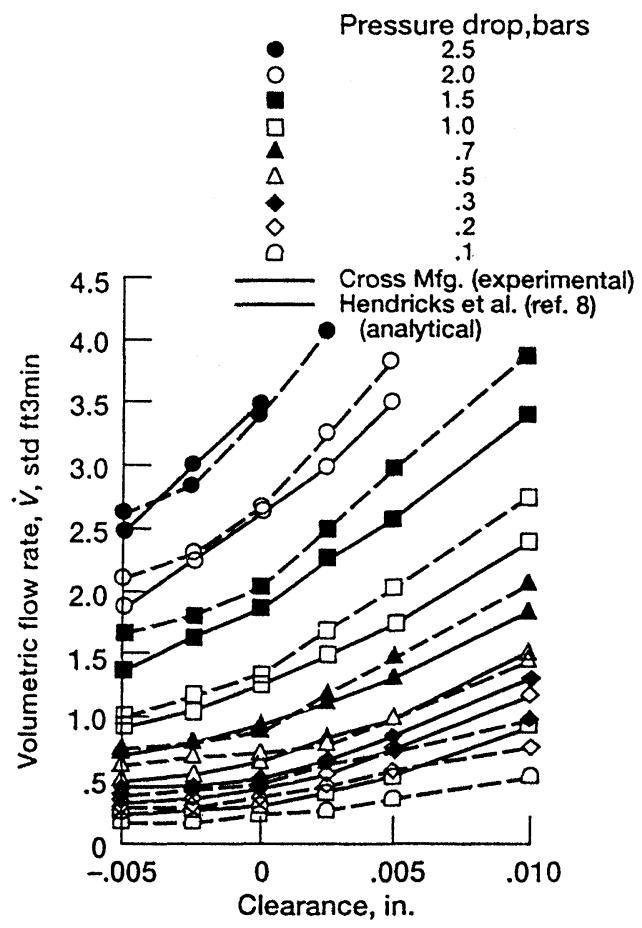

FIGURE 2 Comparison of brush seal bulk flow model with experimental data of Cross Mfg. Ltd.

matched, these sections could not be seen once they were immersed in the oil, but the magnesium oxide flow tracers illuminated by a sheet of laser light provided two-dimensional slices of flows through the sections that were recorded on video tape. Frame-grabbing techniques and software developed were used to quantify these flows.

The simple brush seal bulk flow model and code evolved into more complex forms, ineluding extensions to other gases by using the theory of corresponding states. The code still required geometric information and one data point to determine the flow and pressure drop (Hendricks et al. [1992]; Carlile et al. [1992]). Concurrently, a numerical method was developed to characterize the two-dimensional flow patterns about sets of pins simulating flow patterns in brush seals. The code has been validated experimentally and faithfully reproduced the flow patterns associated with a variety of two-dimensional arrays of pins (Braun and Kudriavtsev [1993]). 


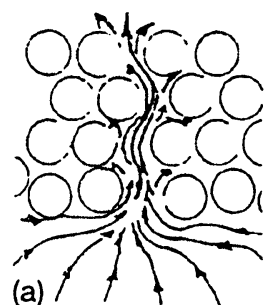

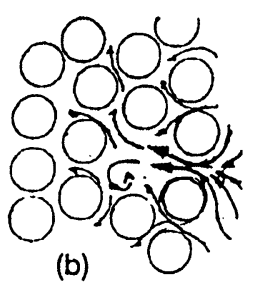

(b)

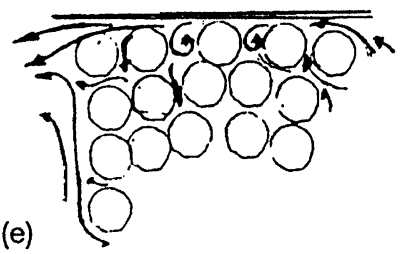

(c)

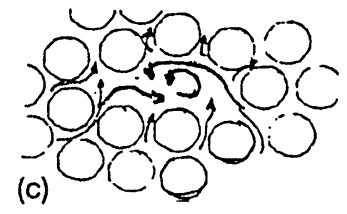

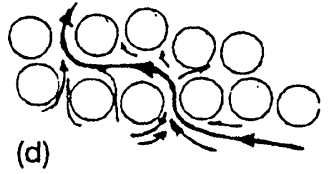

(d)

End-wall flow. (f) Flow at bristle tips. (g) Flow along bristles.

\section{DEVELOPMENT OF CERAMIC BRUSH SEALS}

Testing and modeling brush seal systems (Hendricks et al. [1993]; Hendricks et al. [1991]) including flow, thermal effects, and rubbing effects and projecting the sealing needs of future propulsion systems revealed the need for seals that can withstand high surface speeds and temperatures. Therefore, a brush seal made of silicon carbide bristles and metallic plates and an aluminum oxide brush seal were to be developed. The former is anticipated to operate at $1200 \mathrm{fps}$ and $1500^{\circ} \mathrm{F}$ and is suitable for configurations now in the design stage. The latter is anticipated to operate at $2000^{\circ} \mathrm{F}$ and can be used in the next generation of engines. Both types could be used in static sealing applications.

The craftsmanship of the 5.1-in.-diameter silicon carbide bristle/metallic plate brush seal fabricated and delivered by Cross Mfg. Ltd. was superb. Each bristle appeared to be well manufactured and to be placed as well as any metallic bristle with tips ground to a perfect contour to provide the standard 5-mil interference. Truly a remarkable achievement. The silicon carbide bristle/metallic plate brush seal was installed for flow testing. At first the rotor could be turned in only one direction. After operation it could be rotated by hand in either direction but rotates freely in one direction only. The flow rate

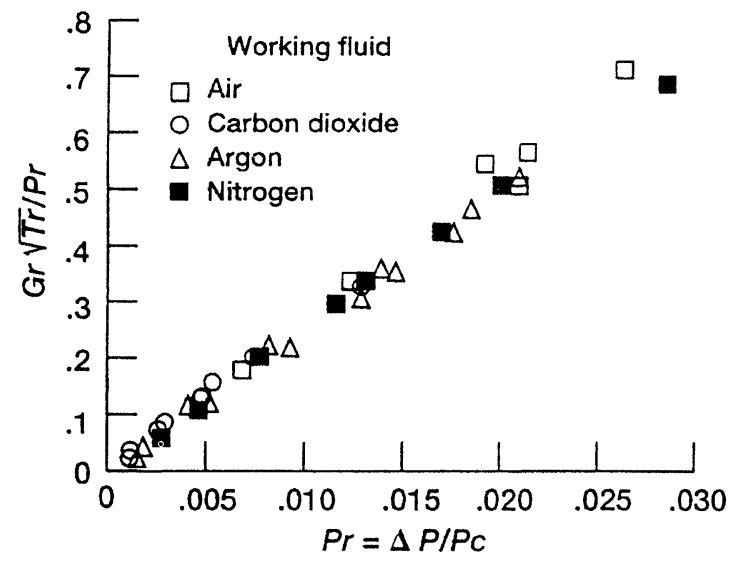

FIGURE 4 Normalized flow data for silicon carbide bristle/ metallic plates brush seal at ambient temperature and $2600 \mathrm{rpm}$, 5.1-in. seal.

data at ambient temperatures were consistent (Fig. 4) considering that a brush seal is not a positive seal system and leaks like a porous medium.

\section{OTHER MODELING EFFORTS}

In addition to the modeling already cited, several other researchers have developed models to correlate and interpret brush seal flow data. These models also require heuristic information and many follow the geometric considerations and 


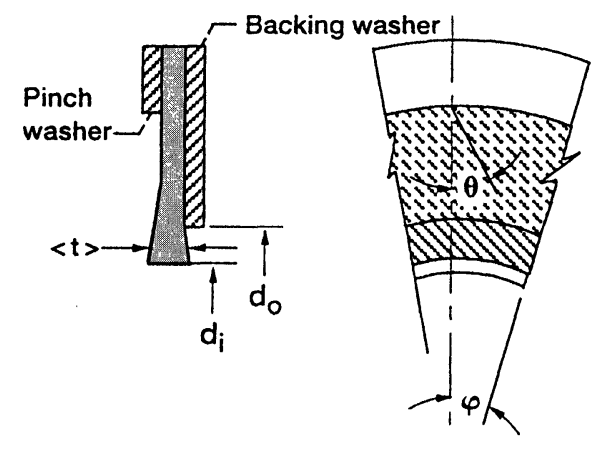

FIGURE 5 Sketch of brush seal geometry.

modeling of the NASA models. In some cases the design methods are characterized, but the details for a pplication are absent. In other cases the results are simply related to a flow coefficient, and others they are related to geometric packing (Holle et al. [1992]) and provide a simple code methodology. Other flexure models follow the NASA bristle loading model. Still others have provided some results for geometric variations (Gorelov et al. [1988]) or for other types of ceramic configurations, such as fiberglass. Although these models and the NASA models provide physical insight into brush seal flow characteristics, the Ergun [1952] porous flow model (with modifications for brush seals, see Fig. 5)

$$
\Delta P=a\left(\frac{\mu}{\mu_{0}}\right) \dot{V}+b\left(\frac{\rho}{\rho_{0}}\right) \dot{V}^{2}
$$

could be used to correlate and predict brush seal flows with simplicity (Fig. 6) where the constants a and $\mathrm{b}$ are empirically determined (Hendricks $e t$ al. [1993]). Two data points would be required to establish geometric and flow parameters, and the gaseous results for simple corresponding-states fluids appear to fit quite well. The effects of surface speed are not well established.

However a direct application of the Ergun model provides useful dimensionless forms:

$$
\begin{aligned}
\Psi & =\frac{\Delta P \bar{\rho}}{G_{\mathrm{o}}^{2}}\left(\frac{1.5 d}{\langle t\rangle} \frac{\varepsilon^{3}}{1-\varepsilon}\right) \\
& =150 /(\operatorname{Re} /(1-\varepsilon))+1.75
\end{aligned}
$$

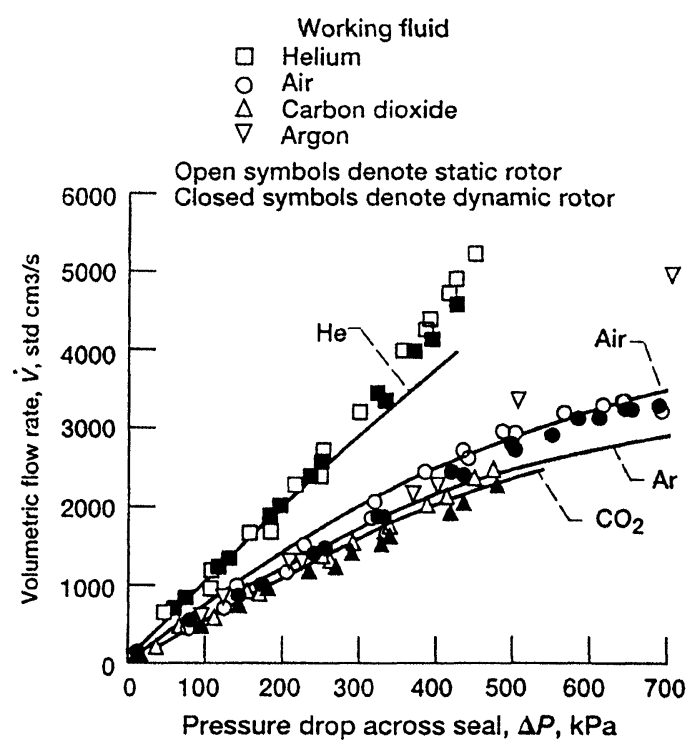

FIGURE 6 Simplified brush seal modeling based on Ergun relation, standard volumetric flow rate verses pressure drop across brush seal for gaseous helium, air (or nitrogen or oxygen), argon, and carbon dioxide. $\Delta P=25 \sqrt{M}\left(\mu / \mu_{0}\right) \dot{V}+$ $0.00015 M\left(\rho / \rho_{0}\right) \dot{V}^{2}$, where $M$ is molecular weight, $\mu$ is viscosity, $\rho$ is density, and subscript zero denotes standard conditions $(1 \mathrm{bar}, 300 \mathrm{~K})$; for helium use $M$ in place of $\sqrt{M}$ and $b=0$. Data from Carlile et al. (5)

$$
\begin{gathered}
R e=1.5 G_{\mathrm{o}} d / \mu \quad G_{\mathrm{o}}=\rho_{0} \dot{V}=\dot{w} / A \\
A=\pi\left(d_{\mathrm{o}}^{2}-d_{\mathrm{i}}^{2}\right) / 4 \quad D_{\mathrm{p}}=1.5 d \\
\varepsilon=V_{\text {open }} / V_{\text {total }}=1-V_{\mathrm{s}} / V_{\mathrm{t}} \\
=1-\pi N_{\mathrm{o}} d^{2} /\left((2)\left(1+d_{\mathrm{o}} / d_{\mathrm{i}}\right)\langle t\rangle \cos (\theta+\varphi)\right) .
\end{gathered}
$$

For a well constructed brush seal, the footprint length becomes

$$
L_{\mathrm{fp}}=\left(d+e_{\mathrm{o}}\right) / \cos (\theta+\varphi),
$$

where $e_{\mathrm{o}}$ is the manufacturing tolerance, and the total number of bristles per row becomes

$$
N_{\theta}=\pi d_{\mathrm{i}} / L_{\mathrm{fp}}
$$

and the upper bound on the thickness and number of rows becomes

$$
\langle t\rangle=d N_{\mathrm{x}}=\pi d d_{\mathrm{i}} N_{\mathrm{o}} / N_{\theta}
$$




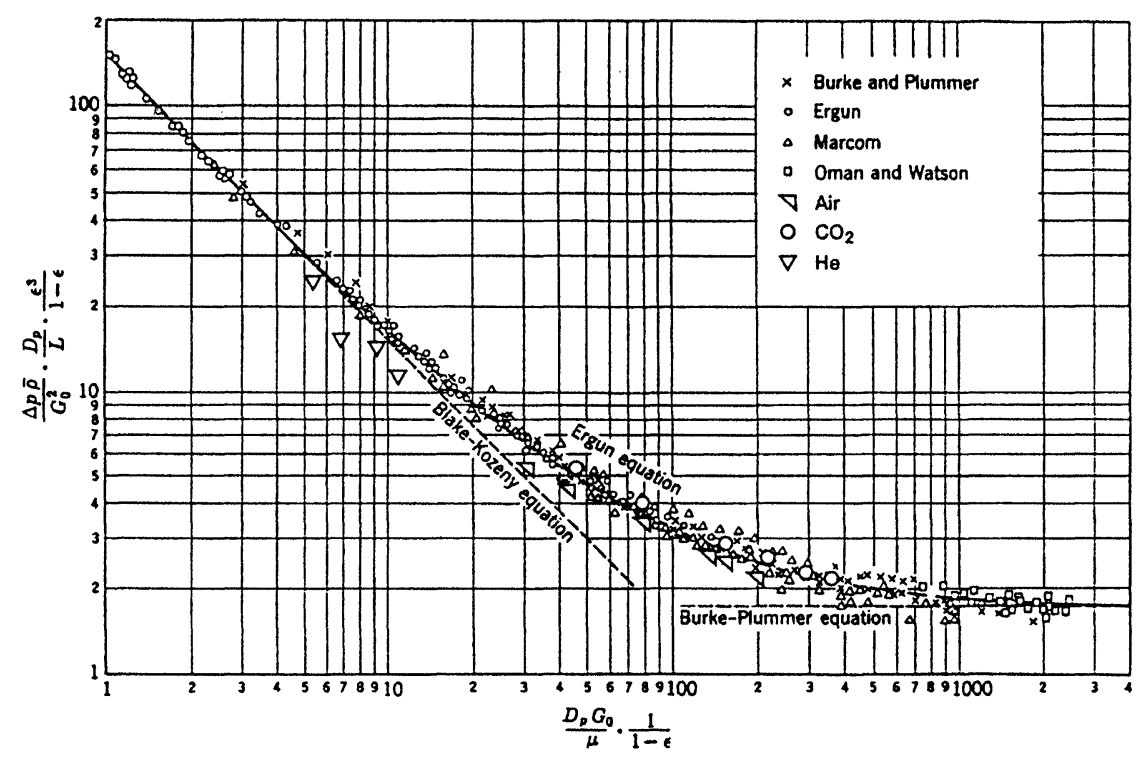

FIGURE 7 Dimensionless flow loss versus Reynolds number taken from Ergun (11) with superimposed brush seal data for air, carbon dioxide, and helium from Carlile et al. (5). Grid background from Bird, R.B.; Stewart, W.E.; and Lightfoot, E.N: Transport Phenomena, John Wiley Press, New York, 1960, p. 200.

where $N_{\mathrm{o}}$ is the number of bristles per unit length as provided by the manufacturer or by micro-examination of the brush interface.

The values of $\Psi$ and $\operatorname{Re} /(1-\varepsilon)$ are calculated from the data set of Carlile et al. [1992] and overplotted on the results presented by Ergun [1952] as illustrated in Fig. 7. The principles of corresponding states were applied to the thermophysical properties used in reduction of the data.

While some differences are noted between the working fluids (helium, air, carbon-dioxide) the major scatter appears at low pressure drops and flow rates where experimental error is most acute. The dynamic leakage at low surface speeds does not differ significantly from the static results except at very low flows. These effects can be seen in the divergence of the helium data at low Reynolds numbers.

And although the results of Fig. 7 appear quite promising, the analysis should be applied with caution as brush seal flows are quite complex (Braun et al. [1990]; Hendricks et al. [1992]; Carlile et al. [1992]; Braun and Kudriavtsev [1993]) and further corroboration is required.

\section{CONCLUSIONS}

Recognizing the propulsion system requirements of next-generation engines, the NASA Lewis Research Center and the U.S. Army Office have modeled brush seal flows and successfully developed, fabricated and flow checked a silicon carbide. bristle/metallic plate brush seal system.

\section{NOMENCLATURE}

$\begin{array}{ll}a, b & \text { Ergun constants, see Fig. } 6 \\ A & \text { flow area without bristles } \\ d & \text { bristle diameter } \\ d_{\mathrm{o}} & \text { fence diameter } \\ d_{\mathrm{i}} & \text { shaft diameter } \\ e_{\mathrm{o}} & \text { manufacturing tolerance } \\ G_{\mathrm{o}} & \text { mass flux without bristles } \\ G_{\mathrm{r}}=G_{\mathrm{o}} / G^{*} & \text { reduced mass flux } \\ G^{*} & \sqrt{\rho_{c} P c / Z c}\left(6010 \mathrm{~g} / \mathrm{cm}^{2}-\mathrm{s} \text { for }\right. \\ & \text { Nitrogen) } \\ L_{\mathrm{fp}} & \text { bristle footprint length }\end{array}$


$M \quad$ molecular weight

$N_{\text {o }} \quad$ number of bristles per unit circumference

$N_{\mathrm{x}} \quad$ number of bristle rows

$N_{\theta} \quad$ number of bristles in a row (circumferential)

$\Delta P$ pressure drop

$R e$ Reynolds number without bristles

$Z \quad$ compressibility (PV/RT)

$\langle t\rangle \quad$ bristle pack thickness

$V \quad$ volume

$\dot{V} \quad$ volumetric flow rate

$\dot{w} \quad$ mass flow rate

$\Psi \quad$ dimensionless flow loss

$\varepsilon \quad$ porosity

$\rho$ density

$\mu \quad$ viscosity

\section{Subscripts}

c thermodynamic critical point

s solid

o reference condition

$\mathrm{t}$ total

\section{References}

Ferguson, J.G. (1988). Brushes as High Performance Gas Turbine Seals, 33rd International Gas Turbine and Aeroengine Congress and Expo., Amsterdam, Netherlands, ASME Paper 88-GT-182.

Flower, R. (1990). Brush Seal Development System, 26th Joint Prop. Conf., Orlando, FL, July 16-18-1990, AIAA Paper 902143 .
Braun, M.J., Hendricks, R.C. and Canacci, V.A. (1990). Flow Visualization in a Simulated Brush Seal, 35th International Gas Turbine and Aeroengine Congress and Expo. Int. Gas Turbine Conf., Brussles, Belgium, ASME Paper 90-GT-217.

Hendricks, R.C., Carlile, J.A., and Liang, A.D. (1992). Some Sealing Concepts-A Review PART A Industrial, Proposed and Dynamic PART B Brush Seal Systems ISROMAC-4, Fourth Int. Symp. on Transport Phenomena and Dynamics of Rotating Machinery, Honolulu, HI, April 5-8, pp. 265-276.

Carlile, J.A., Hendricks, R.C., and Yoder, D.A. (1992). Brush Seal Leakage Performance With Gaseous Working Fluids at Static and Low Rotor Speed Conditions. 37th International Gas Turbine and Aeroengine Congress and Expo. ASME, Cologne, Germany, June 1-4, 1992.

Braun, M.J. and Kudriavtsev, V.V. (1993). Brush Seal Numerical Simulation: Concepts and Advances. Liang, A.D., and Hendricks, R.C. (eds.): Proceedings of 1993 Seals Workshop, NASA Lewis Research Center, Cleveland, Ohio, NASA CP10136, p. 159.

Hendricks, R.C., Griffin, T.A., Bobula, G.A., Bill, R.C. and Howe, H.W. (1993). Integrity Testing of Brush Seal in Shroud Ring of T-700 Engine, 38th International Gas Turbine and Aeroengine Congress and Expo, Cincinnati, Ohio, ASME Paper 93GT372.

Hendricks, R.C., Schlumberger, J., Braun, M.J., Choy, F. and Mullen, R.L. (1991). A Bulk Flow Model of a Brush Seal System, 36th International Gas Turbine and Aeroengine Congress and Expo., Orlando, Florida, ASME Paper 91GT-325.

Holle, G., Chupp, R. and Dowler, C. (1992). Brush Seal Leakage Correlations Based on Effective Thickness, ISROMAC-4 Fourth Int. Symp. on Transport Phenomena and Dynamics of Rotating Machinery, Honolulu, HI, April 5-8, p. 296-304.

Gorelov, G.M., Reznik, V.E. and Tsibizov, V.I. (1988). An Experimental Study of the Rate Characteristics of Brush Seals in Comparison With Labyrinth Seals, Aviatsonnaia Teknika, no. 4 , pp. $43-46$.

Ergun, S. (1952). Fluid Flow Through Packed Columns, Chem Engr. Prog., 43 No. 2, pp. 8994.

Hendricks, R.C., Flower, R. and Howe, H. (1993). Development of a Brush Seals Program Leading to Ceramic Brush Seals, NASA CP-10136, pp. 99-117. 


\section{ait \\ ENERGY MATERIALS}

M A N E Y publishing

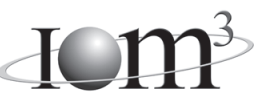

\section{Materials Science \& Engineering for Energy Systems}

Maney Publishing on behalf of the Institute of Materials, Minerals and Mining

The Institute of Materials, Minerals \& Mining

Economic and environmental factors are creating ever greater pressures for the efficient generation, transmission and use of energy. Materials developments are crucial to progress in all these areas: to innovation in design; to extending lifetime and maintenance intervals; and to successful operation in more demanding environments. Drawing together the broad community with interests in these areas, Energy Materials addresses materials needs in future energy generation, transmission, utilisation, conservation and storage. The journal covers thermal generation and gas turbines; renewable power (wind, wave, tidal, hydro, solar and geothermal); fuel cells (low and high temperature); materials issues relevant to biomass and biotechnology; nuclear power generation (fission and fusion); hydrogen generation and storage in the context of the 'hydrogen economy'; and the transmission and storage of the energy produced.

As well as publishing high-quality peer-reviewed research, Energy Materials promotes discussion of issues common to all sectors, through commissioned reviews and commentaries. The journal includes coverage of energy economics and policy, and broader social issues, since the political and legislative context influence research and investment decisions.

\section{CALL FOR PAPERS}

Contributions to the journal should be submitted online at http://ema.edmgr.com

To view the Notes for Contributors please visit: www.maney.co.uk/journals/notes/ema

Upon publication in 2006, this journal will be available via the Ingenta Connect journals service. To view free sample content online visit: www.ingentaconnect.com/content/maney

For further information please contact:

Maney Publishing UK

Tel: +44 (0)113 2497481 Fax: +44 (0)1132486983 Email: subscriptions@maney.co.uk

or

Maney Publishing North America

Tel (toll free): 8662975154 Fax: 6173546875 Email: maney@maneyusa.com

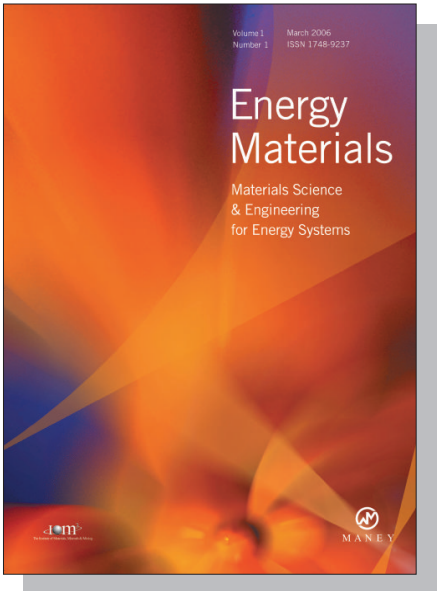

EDITORS

Dr Fujio Abe

NIMS, Japan

Dr John Hald, IPL-MPT, Technical University of Denmark, Denmark

Dr R Viswanathan, EPRI, USA

\section{SUBSCRIPTION INFORMATION}

Volume 1 (2006), 4 issues per year

Print ISSN: 1748-9237 Online ISSN: 1748-9245

Individual rate: $£ 76.00 / U S \$ 141.00$

Institutional rate: $£ 235.00 /$ US $\$ 435.00$

Online-only institutional rate: $£ 199.00 / U S \$ 367.00$

For special $\mathrm{IOM}^{3}$ member rates please email

subscriptions@maney.co.uk

\section{For further information or to subscribe online please visit www.maney.co.uk}



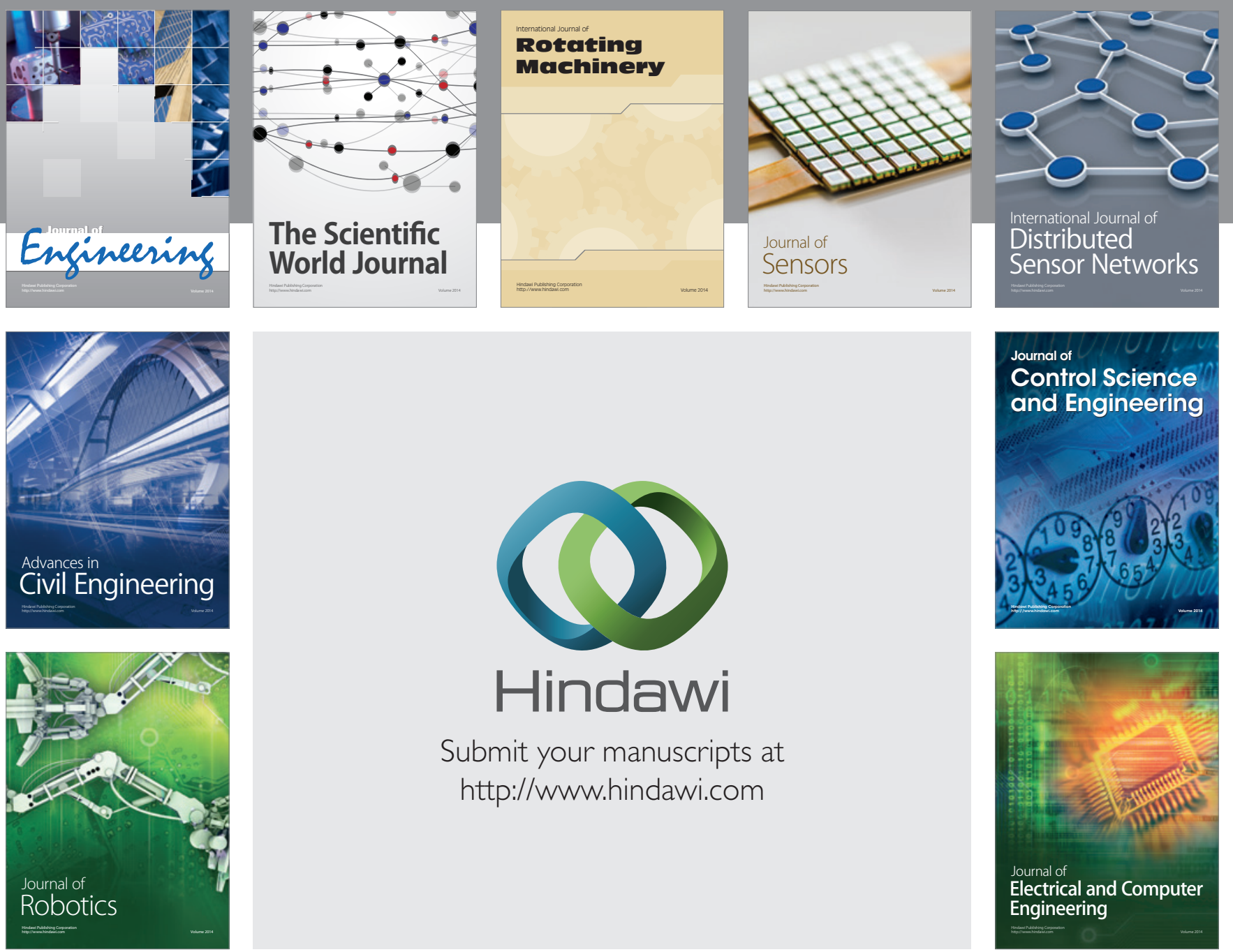

Submit your manuscripts at

http://www.hindawi.com
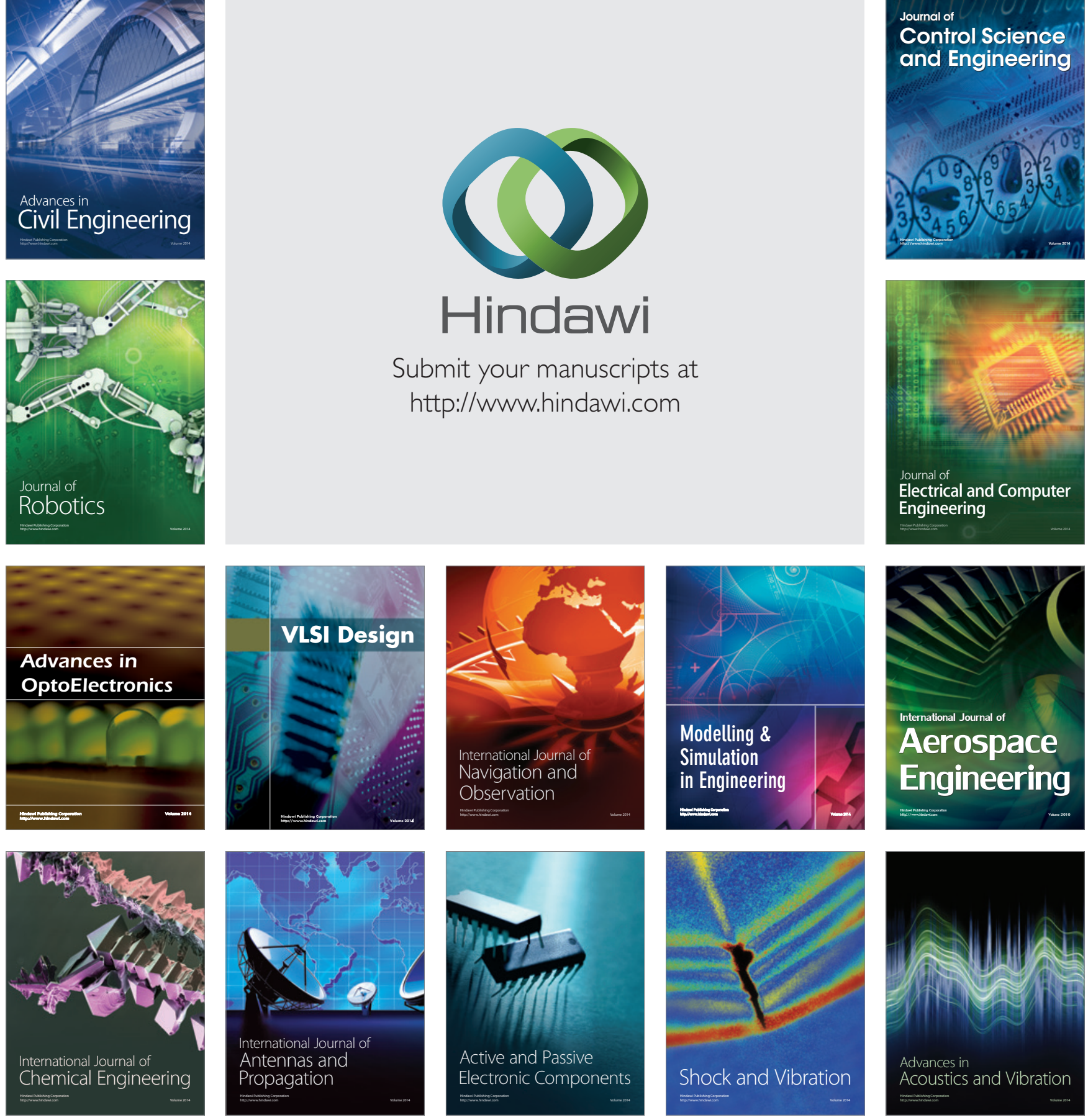